\title{
KAUSALITAS UPAH MINIMUM REGIONAL DENGAN LAJU INFLASI DI PROVINSI D.I. YOGYAKARTA
}

\author{
Mohammad Khaerul Azis \\ Muhammad Ghafur Wibowo \\ UIN Sunan Kalijaga Yogyakarta \\ khoirulazis15@gmail.com
}

\begin{abstract}
This study aims to analyze the causal relationship between the regional minimum wage (UMR) with the rate of inflation, as well as long-term relationship of two variables. Several previous studies have said that there is a unidirectional relationship, both inflation affect UMR, or UMR affecting inflation. There was even a study that found that there is a two-way (reciprocal) between the two. In this study, an analysis tool used is the Vector Autoregression (VAR). From the results, it can be concluded that the relationship between the minimum wage to inflation in the province of DIY is a unidirectional relationship, where inflation affects the amount of the minimum wage set. These results indicate that the regional minimum wage stipulated in Yogyakarta province has been in accordance with the principles of remuneration within the perspective of Islamic Economics as one of the considerations in setting is inflation. Thus, the element of appropriateness as one element in remuneration are met. Through the study also concluded that the regional minimum wage (UMR) with contained inflation long-term relationship.
\end{abstract}

Keywords: minimum wage, inflation, causality, VAR

\section{PENDAHULUAN}

Upah minimum adalah upah bulanan terendah yang terdiri atas upah pokok termasuk tunjangan tetap yang ditetapkan oleh gubernur sebagai jaring pengaman (Peraturan Menteri Tenaga Kerja dan Transmigrasi, 2013). Implikasinya adalah perusahaan atau pemberi kerja tidak diperbolehkan untuk memberikan upah di bawah upah minimum yang ditetapkan oleh pemerintah. Upah minimum ditetapkan berdasarkan kebutuhan hidup layak (KHL) di suatu daerah dengan memperhatikan produktivitas serta pertumbuhan ekonomi, sehingga upah minimum antar daerah berbedabeda. Berdasarkan keputusan menteri tenaga kerja dan transmigrasi nomor 13 tahun 2012, komponen KHL terdiri dari 60 jenis kebutuhan yang harus dipenuhi pekerja selama satu bulan, jumlah ini merupakan perubahan dari peraturan sebelumnya yang termuat dalam keputusan menteri tenaga kerja dan transmigrasi nomor 17 tahun 2005 yang berjumlah 46 komponen KHL.

Pemerintah menetapkan upah minimum untuk menciptakan keadilan antara pengusaha dengan pekerja (Gie, 1996: 422). Menurut Afzalurrahman (1997: 297), penetapan besarnya tingkat upah dilakukan dengan cara negosiasi antara pekerja (buruh), majikan (pengusaha), dan negara (pemerintah). Kepentingan buruh dan pengusaha diperhitungkan dengan adil sampai 
terjadinya kesepakatan di antara keduanya. Peran pemerintah dalam hal ini adalah menjadi fasilitator untuk memastikan agar upah yang ditetapkan tidak terlalu rendah sehingga kesejahteraan buruh terabaikan, serta tidak terlalu tinggi yang menyebabkan pengusaha mengalami kerugian.

Salah satu komponen yang mempengaruhi besarnya upah minimum adalah laju inflasi. Inflasi berakibat pada meningkatnya harga-harga kebutuhan yang diperlukan oleh masyarakat dalam hal ini pekerja. Apabila besarnya upah minimum tidak memperhatikan laju inflasi, maka secara tidak langsung besarnya upah riil yang diterima oleh pekerja berkurang karena jumlah barang-barang kebutuhan yang dapat dibeli berkurang.

Secara umum terdapat beberapa faktor penyebab timbulnya inflasi sehingga inflasi dibagi menjadi beberapa jenis. Salah satu jenis inflasi yaitu Cost Push Inflation (Inflasi Tarikan Biaya). Cost Push Inflation merupakan inflasi yang timbul karena adanya kenaikan biaya produksi.

Penetapan tingkat upah minimum yang dilakukan oleh pemerintah dapat mendorong peningkatan laju inflasi seperti hasil penelitian yang dilakukan oleh Siallagan (2015). Inflasi terjadi ketika upah minimum yang ditetapkan oleh pemerintah terlalu besar. Upah minimum merupakan bagian dari faktor produksi yang harus dikeluarkan oleh perusahaan. Hal ini akan berakibat pada meningkatnya biaya produksi yang harus dikeluarkan oleh perusahaan. Dampak yang ditimbulkan dari peningkatan biaya produksi tersebut adalah perusahaan menaikkan harga barang yang dihasilkan untuk dapat mencapai profit margin yang diharapkan. Kenaikan hargaharga berbagai macam barang yang terjadi secara serentak inilah yang disebut dengan inflasi.

Di sisi lain, laju inflasi mempengaruhi tingkat upah sebagaimana hasil penelitian yang dilakukan oleh Hess (2000) dan Jonsson
(2004). Peningkatan laju inflasi berdampak pada menurunnya jumlah pendapatan riil yang dapat dikeluarkan oleh pekerja untuk memenuhi kebutuhannya. Ketika laju inflasi meningkat dan tidak disertai dengan kenaikan tingkat upah maka pendapatan riil pekerja menurun yang berdampak pada menurunnya tingkat kesejahteraan.

Terdapat dua alasan dipilihnya provinsi Daerah Istimewa Yogyakarta (DIY) sebagai obyek dalam penelitian ini. Pertama, tingkat upah minimum di provinsi DIY masih dibawah tingkat upah minimum rata-rata nasional. Gambar 1 berikut merupakan grafik perbandingan antara upah minimum regional DIY dengan upah minimum rata-rata nasional dari tahun 20072012:

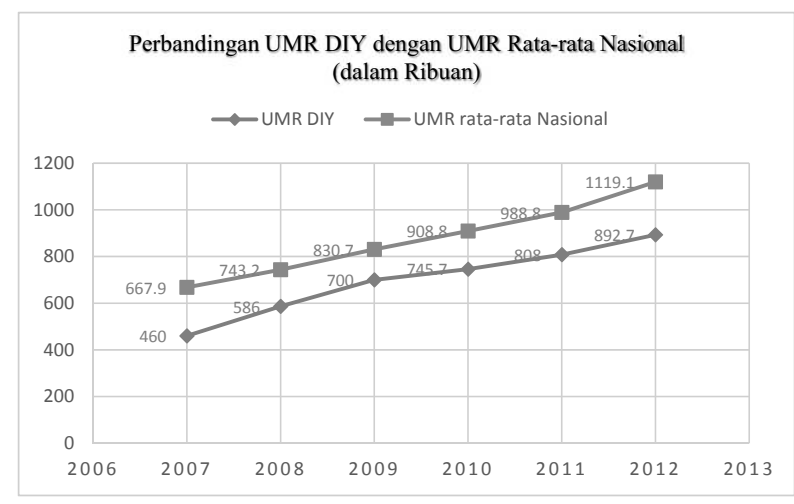

Sumber: Badan Pusat Statistik (BPS), 2014

\section{Gambar 1 \\ Perbandingan UMR DIY dengan Upah Minimum Rata-Rata Nasional Tahun 2007- 2012}

Akan tetapi, laju inflasi di provinsi DIY dalam kurun waktu antara tahun 2007-2012 selalu lebih tinggi dari inflasi nasional, kecuali pada tahun 2008 dimana inflasi nasional di atas inflasi DIY. Gambar 2. menunjukkan grafik laju inflasi provinsi DIY dengan inflasi nasional dalam kurun waktu dari tahun 2007 sampai dengan tahun 2012: 


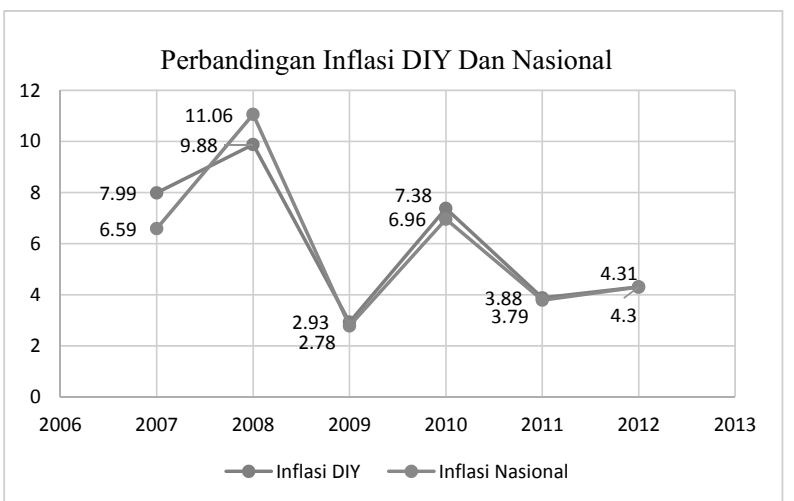

Sumber: Badan Pusat Statistk (BPS) dan BAPPEDA DIY, 2014

\section{Gambar 2}

Perbandingan Inflasi DIY dan Nasional Tahun 2007-2012

Berdasarkan dua gambar di atas, bila mengacu pada teori cost push inflation seharusnya tingkat upah minimum yang relatif rendah di provinsi DIY dibandingkan dengan upah minimum rata-rata nasional akan berdampak pada lebih rendahnya nilai inflasi di provinsi DIY daripada inflasi yang terjadi dalam skala nasional. Namun faktanya, rendahnya UMR DIY dibandingkan dengan UMR rata-rata nasional tidak diikuti dengan rendahnya nilai inflasi di provinsi DIY.

Penelitian ini bertujuan untuk menganalisis akibat dari penetapan upah minimum terhadap inflasi, atau inflasi yang mempengaruhi besarnya upah minimum yang ditetapkan, serta manganalisis apakah diantara keduanya terjadi hubungan dua arah. Selain itu, penelitian ini bertujuan untuk menguji ada atau tidaknya keterkaitan antara keduanya dalam jangka panjang.

\section{REVIEW LITERATUR DAN HIPOTESIS}

\section{Cost Push Inflation}

Cost push inflation merupakan inflasi yang timbul karena adanya kenaikan biaya produksi. Kenaikan biaya produksi menyebabkan penurunan tingkat produksi. Permintaan terhadap barang/jasa tetap atau meningkat, sedangkan tingkat produksi menurun akan menyebabkan kenaikan harga.

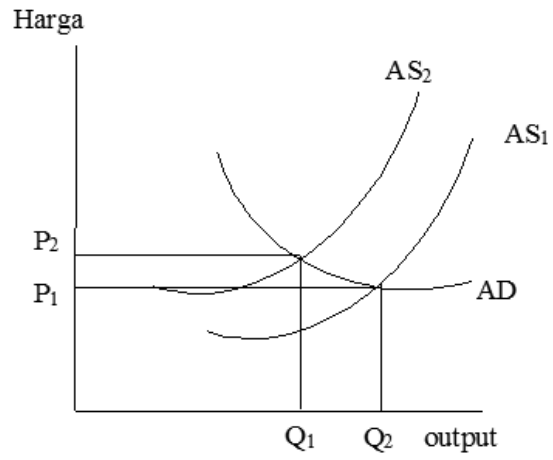

\section{Gambar 3 Cost Push Inflation}

Cost push inflation dapat dijelaskan melalui gambar 3. misalkan permintaan agregat ditunjukkan oleh kurva AD dan penawaran agregat ditunjukkan oleh kurva $\mathrm{AS}_{1}$ dan $\mathrm{AS}_{2}$. Pada saat biaya produksi yang harus dikeluarkan oleh produsen meningkat, misal karena buruh meminta kenaikan upah. Maka produsen akan mengurangi jumlah barang yang diproduksi sebagai akibat dari meningkatnya biaya produksi. Sehingga kurva penawaran agregat $\mathrm{AS}_{1}$ berpindah ke $\mathrm{AS}_{2}$. Perpindahan tersebut mengakibatkan tingkat harga menjadi naik dari $\mathrm{P}_{1}$ ke $\mathrm{P}_{2}$.

\section{Permintaan Tenaga Kerja}

Permintaan dalam konteks ekonomi seperti yang dikutip oleh Sholeh (2007: 62) dalam Sudarsono (1990) didefinisikan sebagai jumlah maksimum suatu barang atau jasa yang dikehendaki oleh pembeli untuk dibelinya pada setiap kemungkinan harga dalam jangka waktu tertentu. Dalam kaitannya dengan tenaga kerja, permintaan tenaga kerja adalah hubungan antara tingkat upah dan jumlah pekerja yang 
dikehendaki oleh pengusaha untuk dipekerjakan. Sehingga dapat disimpulkan bahwa permintaan tenaga kerja merupakan jumlah tenaga kerja yang dipekerjakan oleh pengusaha pada setiap kemungkinan tingkat upah dalam jangka waktu tertentu.

Permintaan tenaga kerja digambarkan oleh kurva berikut ini:

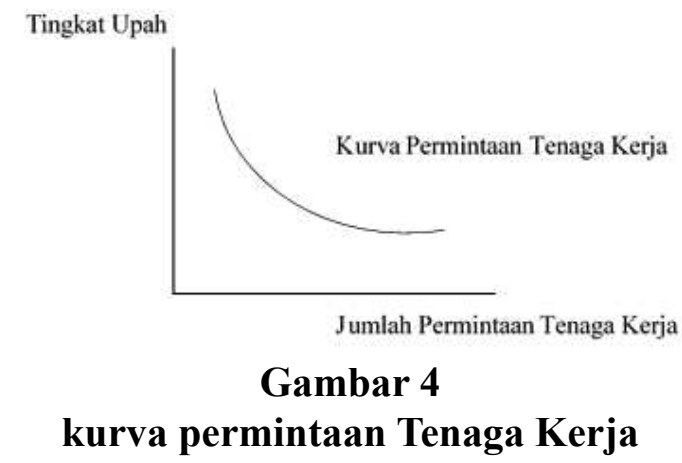

Gambardi atas menunjukkan bahwa ketika tingkat upah tinggi maka jumlah permintaan tenaga kerja berkurang, dan sebaliknya bila tingkat upah rendah maka jumlah permintaan tenaga kerja meningkat. Hal ini bertujuan untuk memaksimalkan keuntungan perusahaan (Williamson, 2014: 131).

\section{Upah Minimum dalam Perspektif Ekonomi Syariah}

Upah minimum adalah upah bulanan terendah yang terdiri atas upah pokok termasuk tunjangan tetap yang ditetapkan oleh gubernur sebagai jaring pengaman (Peraturan Menteri Tenaga Kerja dan Transmigrasi, 2013). Menurut Mohammad Darwis sebagaimana dikutip oleh Heri Setiawan (2014: 14), Standar kelayakan upah dalam Islam tidak diatur secara praktis sistem dan besaran upah yang layak untuk diberikan, tetapi Islam memberi gambaran umum bagaimana etika pemberian upah. Islam lebih menekankan pada konsep moral, tidak hanya sebatas materi tetapi menembus batas kehidupan yakni dimensi akhirat, yang disebut pahala. Rambu-rambu pengupahan dalam Islam ada 2 yaitu adil dan layak, adil bermakna jelas dan transparan serta proposional, sebagaimana sebuah hadits yang diriwayatkan oleh Baihaqi berikut:

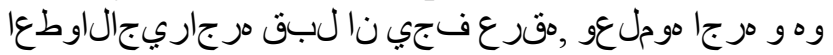

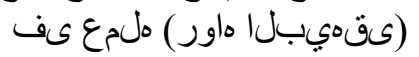

Hadits tersebut menerangkan bahwa pengusaha harus segera memberikan upah kepada pekerja. Selain itu, hadits tersebut menerangkan tentang kejelasan akad (transaksi) dalam hal ini jumlah besaran upah yang disepakati bersama antara pengusaha dan pekerja, serta proporsionalitas upah yang diberikan atas pekerjaan yang telah dilakukan.

Sedangkan layak berarti cukup pangan, sandang, papan serta sesuai dengan keadaan ekonomi saat itu. Allah SWT. telah berfirman dalam Al-Qur'an surat Al-Syu'ara (26) ayat 183: ضر الا يف وث عت ال و مهءايشا سانلا وسخبت الو

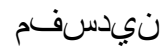

Ayat di atas bermakna bahwa janganlah seseorang merugikan orang lain, dengan mengurangi hak-hak yang semestinya diterima olehnya. Dalam pengertian yang lebih jauh, janganlah seorang pengusaha mempekerjakan pekerja dengan memberikan upah di bawah produktivitas yang telah diberikan oleh pekerja. Hal ini karena berarti pengusaha mengurangi hak-hak yang semestinya didapat oleh pekerja (Zaenal, 2014: 574).

\section{Penelitian Terdahulu}

Penelitan yang dilakukan oleh Faith Christian Q. Cacnio dengan judul penelitian "Do Higher Wages Cause Inflation?". Hasil penelitiannya menunjukkan bahwa dengan menggunakan uji granger causality, terdapat hubungan antara perubahan upah dengan laju inflasi yang terjadi secara timbal balik. Perubahan upah berpengaruh positif terhadap laju inflasi dan laju inflasi juga berpengaruh positif terhadap perubahan upah. Dalam penelitian yang dilakukan oleh Faith Christian Q. Cacnio, 
perubahan upah tidak berdampak terhadap inflasi dalam kurun waktu kurang 6 bulan, akan tetapi akan berdampak terhadap inflasi antara rentang waktu 6 sampai 12 bulan. Menurut Faith terdapat dua alasan mengenai hal ini. Pertama, dalam jangka pendek konsumen tidak merubah kebiasaan konsumsinya meskipun upah yang diterima meningkat. Akan tetapi, konsumen kemudian menyadari bahwa tingkat upahnya meningkat yang direspon dengan meningkatkan jumlah konsumsinya sehingga permintaan terhadap barang meningkat. Sesuai dengan teori permintaan, meningkatnya permintaan akan berdampak pada naiknya harga. Apabila kenaikan harga tersebut terjadi secara agregrat maka akan berdampak pada meningkatnya laju inflasi.

AdriatikHoxhadenganjudulpenelitiannya "Causality Between Prices And Wages: VECM Analysis For EU-12" menunjukkan hasil bahwa antara upah dengan harga terdapat hubungan kausalitas yang saling mempengaruhi. Kausalitas tersebut terjadi dalam jangka panjang yang dibuktikan dengan uji kointegrasi maupun yang terjadi dalam jangka pendek melalui uji Vector Error Correction Model (VECM).

Penelitian yang dilakukan oleh Siallagan dengan judul penelitian "Analisis Kausalitas Antara Upah Minimum dan Tingkat Inflasi di Kota Medan" menunjukkan hasil bahwa hubungan antara upah minimum dengan inflasi di kota medan tidak memiliki hubungan timbal balik atau dua arah, melainkan hanya searah, dimana upah minimum mempengaruh inflasi.

\section{Hipotesis}

Berdasarkan latar belakang masalah, perumusan masalah, tujuan penelitian serta telaah pustaka yang telah diuraikan di atas, maka disusun hipotesis sebagai berikut:

$\mathrm{H}_{1}$ : Terdapat hubungan kausalitas (sebab akibat) antara besarnya upah minimum provinsi dengan laju inflasi.
$\mathrm{H}_{2}$. Terdapat hubungan jangka panjang antara besarnya upah minimum provinsi dengan laju inflasi.

\section{METODE PENELITIAN}

Penelitian ini merupakan jenis penelitian kuantitatif. Penelitian kuantitatif merupakan penelitian yang menggunakan data-data berupa angka yang pasti. Data mentah yang diperoleh dari berbagai sumber yang berwenang dalam menerbitkan data-data tersebut seperti Badan Pusat Statistik dan Dinas Tenaga Kerja dan Transmigrasi, kemudian diolah dengan menggunakan alat analisis model Vector Auto Regression (VAR) sehingga menghasilkan informasi yang berguna untuk pengambilan keputusan.

\section{Definisi Operasional Variabel}

a. Upah minimum adalah upah bulanan terendah yang meliputi upah pokok dan tunjangan tetap. Upah minimum ditetapkan setiap tahunnya berdasarkan nilai kebutuhan hidup layak (KHL). Dalam penelitian ini variabel yang digunakan adalah upah minimum regional DIY. Sebelum tahun 2013, penetapan upah minimum di Provinsi DIY menggunakan sistem Upah Minimum Regional (UMR), yang berarti bahwa semua kabupaten/kota yang berada di Provinsi DIY memiliki tingkat upah minimum yang sama. Akan tetapi, sejak tahun 2013 Provinsi DIY menggunakan sistem Upah Minimum Kabupaten (UMK) dalam menetapkan besarnya tingkat upah minimum di Provinsi DIY. Hal ini berarti bahwa masing-masing kabupaten/kota di Provinsi DIY memiliki tingkat upah minimum yang berbeda. Oleh karena itu, penelitian ini menggunakan rentang waktu dari tahun 1990 sampai dengan tahun 2012.

Inflasi adalah kenaikan harga-harga barang dan jasa secara umum dimana barang 
dan jasa tersebut merupakan kebutuhan pokok masyarakat atau turunnya daya jual mata uang suatu negara. Inflasi dihitung berdasarkan rumusan persamaan sebagai berikut:

\section{Teknik Estimasi}

Metode yang digunakan dalam penelitian ini adalah dengan menggunakan model Vector Auto Regression (VAR). Model analisis VAR merupakan model nonstruktural atau model ateoritis karena dibangun dengan meminimalkan pendekatan teori-teori ekonomi. Model VAR digunakan karena mampu menangkap fenomenafenomena ekonomi dengan baik (Widarjono, 2013: 331).

VAR merupakan sistem $n$ persamaan dengan jumlah variabel endogen sebanyak $n$, dimana masing-masing variabel dijelaskan oleh lagnya sendiri, nilai-nilai sekarang dan masa lalu variabel endogen lainnya dalam model. Oleh sebab itu, dalam konteks ekonometrika modern, VAR dianggap sebagai multivariate-time series yang membahas semua variabel endogen, karena tidak ada kepastian bahwa variabel sebenarnya eksogen, dan VAR sepenuhnya bertumpu pada data untuk menjelaskan apa yang sebenarnya terjadi (Ascarya, 2012: 300).

Pada penelitian ini, UMR pada periode $\mathrm{t}$ diduga dipengaruhi oleh inflasi pada waktu $\mathrm{t}$ dan UMR pada $\mathrm{t}-1$, model regresinya dapat diformulasikan sebagai berikut:

Di sisi lain, pergerakan UMR pada gilirannya akan memengaruhi pergerakan inflasi di masa yang akan datang, sehingga dapat diformulasikan model regresi dengan persamaan sebagai berikut:

Secara umum langkah-langkah dalam analisis menggunakan model VAR yaitu dimulai dengan uji stasioneritas data, lalu uji panjang kelambanan (lag) yang optimal, kemudian uji stabilitas VAR, setelah itu uji kausalitas Granger, dilanjutkan dengan uji kointegrasi, estimasi model VAR, Impulse Response Function (IRF), dan Forecast Error Variance Decompotition. Secara sederhana langkah-langkah tersebut digambarkan dalam grafik berikut:

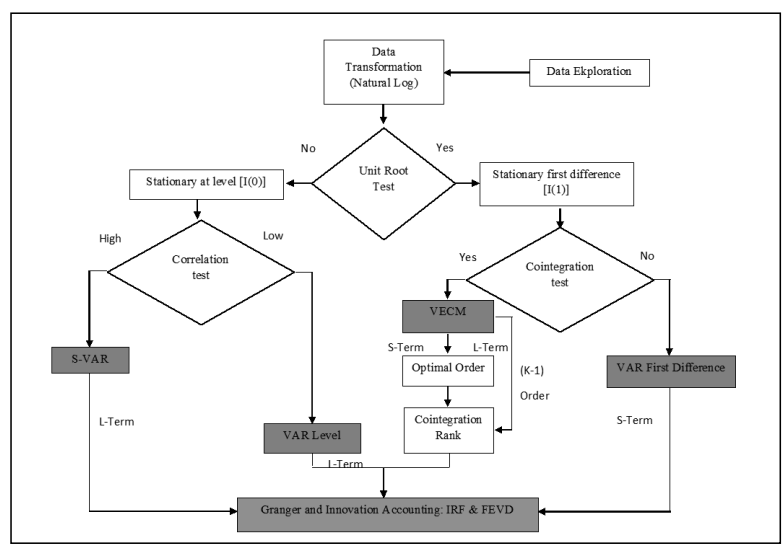

Sumber: Ascarya (2012: 302)

\section{Gambar 5 Proses Analisis VAR} berikut:

Langkah-langkahnya adalah sebagai

Langkah 1: Menguji stasioneritas data. Pada tahap ini semua data ditransformasikan ke bentuk logaritma, kecuali data dalam bentuk persentase. Setelah itu dilakukan pengujian stasioneritas data dengan menggunakan software Eviews 8.0. Pengujian dengan menggunakan model Augmented DickeyFuller (ADF).

Langkah 2: Jika data stasioner pada tingkat level maka langkah selanjutnya adalah uji korelasi, namun jika data stasioner pada first difference maka langkah selanjutnya adalah uji kointegrasi.

Langkah 3: Uji korelasi. Apabila hasil dari uji korelasi menunjukkan bahwa data berkorelasi tinggi maka analisis menggunakan S-VAR, jika bekorelasi rendah maka menggunakan VAR level lalu kemudian dilakukan uji granger, IRF dan FEVD. 
Langkah 4: Uji kointegrasi. Apabila data yang diuji menunjukkan bahwa terdapat kointegrasi maka model analisis yang digunakan adalah VECM, sedangkan apabila data tidak menunjukkan adanya kointegrasi maka analisis menggunakan VAR First Difference.

Langkah 5: Uji kausalitas Granger. Uji kausalitas Granger bertujuan untuk melihat hubungan antar variabel, baik hubungan searah maupun hubungan yang saling mempengaruhi (timbal balik).

Langkah 6: Analisis Impulse Response Function (IRF) digunakan untuk melihat respon masing-masing variabel terhadap guncangan yang terjadi pada dirinya maupun pada variabel lain yang digunakan dalam model. Sedangkan Forecast Error Variance Decompotition (FEVD) digunakan untuk melihat kontribusi positif dari masing-masing variabel yang digunakan dalam model.

Dari keenam langkah tersebut akan diperoleh hasil dari tujuan penelitian ini yaitu ada/tidaknya hubungan kausalitas Granger dan hubungan jangka panjang yang terjadi pada kedua variabel yang diteliti.

\section{HASIL PENELITIAN DAN PEMBAHASAN}

Hasil uji stasioneritas data menunjukkan bahwa hanya variabel inflasi yang stasioner pada tingkat level, sedangkan variabel UMR stasioner pada tingkat diferensiasi. Langkah selanjutnya adalah menentukan panjang lag yang optimal. Panjang lag optimal dapat diperoleh dengan cara mencari nilai AIC, SIC, dan HQ yang paling rendah. Hasil dari pengujian menunjukkan bahwa nilai lag optimalnya adalah 5 .

\section{Analisis Hubungan Kausalitas antara UMR dengan Inflasi}

Berdasarkan hasil uji kausalitas Granger menunjukkan hasil bahwa hubungan yang terjadi antara UMR dengan inflasi merupakan hubungan yang searah (unidirectional causality), dimana variabel inflasi memengaruhi variabel UMR. Hasil ini diperoleh dari nilai probabilitas inflasi terhadap UMR sebesar $6,11 \%$ lebih kecil dari nilai $\alpha=10 \%$.

Tabel 1

Hasil Uji Kausalitas Granger

\begin{tabular}{l}
\begin{tabular}{ll|r|r|r|}
\hline $\begin{array}{l}\text { Pairwise Granger Causality Tests } \\
\text { Sample: } 19902012 \\
\text { Lags: } 5\end{array}$ & Obs & F-Statistic & Prob. \\
\hline Null Hypothesis: & 15 & 5.54130 & 0.0611 \\
\hline DDDINF does not Granger Cause DDDLNUMR & & 1.98496 & 0.2631 \\
DDDLNUMR does not Granger Cause DDDINF & &
\end{tabular} \\
\hline
\end{tabular}

Sumber: hasil olah data (2016)

Selain itu, hasil ini diperkuat dengan hasil dari pengujian IRF dan Variance Decompotition. Dari hasil uji IRF, sejak periode pertama, kejutan (shock) yang diberikan variabel inflasi menyebabkan respon yang positif terhadap variabel UMR dengan nilai yang cukup besar yaitu 24,99\%. Kemudian dari hasil uji variance decompotition menunjukkan bahwa variabel UMR berkontribusi variasi secara positif terhadap variabel inflasi sejak dari periode pertama.

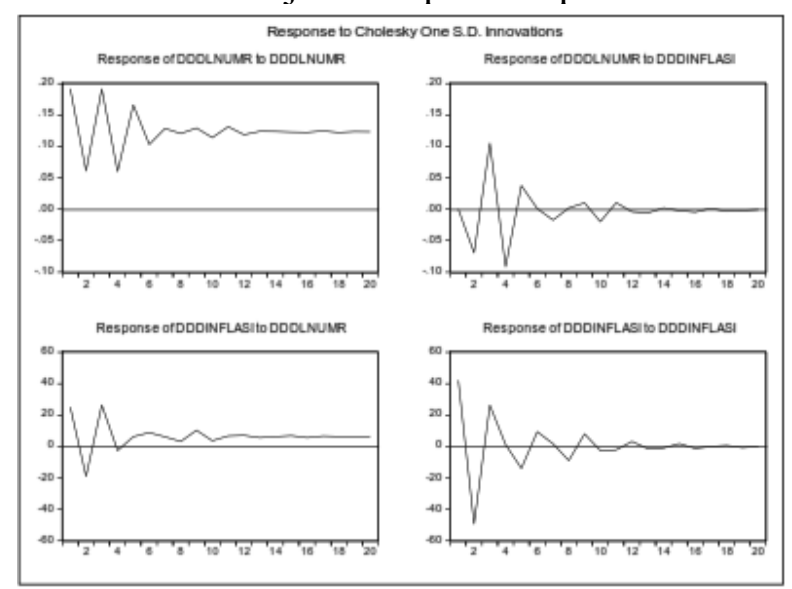

Sumber: hasil olah data (2016)

\section{Gambar 6 Impulse Response}

Hasil ini sejalan dengan penelitian yang pernah dilakukan oleh Hess (2000) dan Jonsson (2004), serta berkebalikan dengan penelitian yang dilakukan oleh Sialagan (2015). Penjelasan 
dari hasil ini adalah komponen hidup layak (KHL) sebagai pertimbangan utama dalam menetapkan upah minimum setiap tahunnya mengalami peningkatan. Peningkatan tersebut disebabkan oleh inflasi yang terjadi di provinsi DIY khususnya dan inflasi yang terjadi secara nasional pada umumnya. Oleh karena itu, untuk menetapkan upah minimum regional, salah satu komponen yang harus diperhatikan adalah inflasi. Berdasarkan hasil analisis deskriptif, ratarata inflasi di provinsi DIY relatif besar dengan nilai rata-rata sebesar $11,05 \%$. Namun, rata-rata UMR pada periode yang sama relatif rendah dengan nilai rata-rata sebesar 318.378,43. Maka dalam menetapkan UMR perlu dipertimbangkan inflasi yang terjadi pada saat ini serta inflasi yang terjadi di masa yang akan datang. Hal ini karena berdasarkan uji variance decompotition, kontribusi varian variabel UMR cukup besar memengaruhi perubahan variabel inflasi di masa depan.

\section{Analisis Hubungan Jangka Panjang antara UMR dan Inflasi}

Tujuan dari analisis jangka panjang adalah untuk mengetahui terdapat atau tidaknya kesamaan pergerakan dan stabilitas hubungan di antara variabel-variabel di dalam penelitian. Berdasarkan uji kointegrasi dengan menggunakan uji Johansen nilai trace statistic dan nilai maxeigen statistic lebih besar dari nilai critical value (lihat tabel 3). Nilai trace statistic dan max-eigen statistic yang lebih besar dari nilai critical value ini menandakan bahwa antara kedua variabel terdapat kointegrasi. Hal ini berarti antara variabel UMR dan variabel inflasi terdapat hubungan jangka panjang.

Tabel 3

\section{Hasil Uji Kointegrasi}

\begin{tabular}{|c|c|c|c|}
\hline \multirow{2}{*}{ Trace Statistic } & 42.82507 & \multirow{2}{*}{ Critical Value } & 12.32090 \\
\cline { 2 - 2 } Max-Eigen Statistic & 15.49492 & & 4.129906 \\
\cline { 2 - 2 } Critical Value & 11.22480 \\
\cline { 2 - 2 } & 27.33015 & 4.129906 \\
\hline
\end{tabular}

Sumber: hasil olah data (2016)
Implikasinya adalah antara variabel UMR dan variabel inflasi di provinsi DIY akan saling memengaruhi di masa mendatang. Hal ini tentu saja dengan menganggap variabel lain tidak ada (disturbance term). Hasil ini sejalan dengan penelitian yang dilakukan oleh Adriatik Hoxha (2010) dan Budianto Sialagan (2015).

\section{Analisis Hasil dengan Pendekatan Ekonomi Islam}

Islam tidak pernah merumuskan besaran upah yang harus di berikan oleh pengusaha kepada pekerja. Akan tetapi, Islam memberikan ramburambu dalam pemberian upah agar pengusaha tidak memberikan upah terlalu rendah yang bertujuan untuk mengeksploitasi para pekerja dengan cara mempekerjakan secara berlebihan dengan pemberian upah di bawah produktivitas yang telah diberikan.

Sesuai dengan rambu-rambu dalam pemberian upah dalam Islam, dapat diambil kesimpulan bahwa upah minimum yang ditetapkan haruslah sesuai dengan produktivitas pekerja atas suatu pekerjaan serta kondisi ekonomi pada saat itu. Produktivitas pekerja dapat diukur berdasarkan jumlah barang atau jasa yang dihasilkan oleh pekerja dalam waktu tertentu. Sedangkan kondisi ekonomi dapat di nisbatkan pada laju inflasi yang terjadi, alasannya karena inflasi merupakan masalah dalam suatu perekonomian.

Sebelum menetapkan upah minimum, pemerintah melalui dinas terkait melakukan survei terhadap harga-harga barang yang tergolong sebagai komponen hidup layak (KHL). Terjadinya inflasi menyebabkan harga-harga barang yang tergolong komponen hidup layak tersebut meningkat. Jika hal ini tidak direspon dengan peningkatan upah yang diberikan kepada pekerja, maka upah riil yang diterima pekerja menurun. Sehingga kebutuhan yang seyogyanya harus dipenuhi menjadi tidak terpenuhi. Oleh karena itu, inflasi merupakan faktor terpenting dalam penetapan upah minimum. 
Berdasarkan hasil dari penelitian ini yang dilakukan dengan melakukan pengujian terhadap variabel UMR dan Inflasi dengan menggunakan model VAR, menunjukkan bahwa inflasi merupakan salah satu faktor yang memengaruhi besarnya UMR di provinsi DIY. Hal ini menunjukkan bahwa dalam penetapan UMR di provinsi DIY telah mempertimbangkan unsur keadilan dan kelayakan bagi pekerja. Hal ini berarti bahwa penetapan UMR di provinsi DIY telah sesuai dengan kaidah penetapan upah dalam Islam.

\section{KESIMPULAN DAN SARAN}

\section{Kesimpulan}

Berdasarkan dari hasil estimasi dan analisis yang dilakukan dengan model Vector Autoregression (VAR), serta pembahasan yang telah dilakukan pada bab IV dengan variabel amatan UMR dan inflasi, dapat ditarik beberapa kesimpulan:

a. Hubungan antara upah minimum regional dengan laju inflasi dari tahun 1990 hingga tahun 2012 menunjukkan hubungan yang searah (unidirectional relationship), yaitu variabel perubahan laju inflasi berpengaruh secara Granger terhadap variabel perubahan upah minimum regional (UMR) di provinsi DIY. Hal ini menunjukkan bahwa variabel inflasi merupakan salah satu faktor yang mempengaruhi jumlah upah minimum regional. Sementara itu, variabel perubahan UMR tidak memberikan pengaruh terhadap peningkatan laju inflasi.

b. Berdasarkan hasil analisis uji kointegrasi Johansen dapat ditarik kesimpulan bahwa terdapat hubungan jangka panjang antara upah minimum regional dan laju inflasi di provinsi DIY. Hal ini menunjukkan bahwa dalam jangka panjang kedua variabel akan saling memengaruhi.

\section{Saran}

Berdasarkan penelitian yang telah penyusun lakukan, terdapat beberapa saran untuk menjadi bahan pertimbangan bagi akademisi dalam penelitian-penelitian selanjutnya dan pihak-pihak yang berwenang dalam menetapka upah minimum regional, antara lain sebagai berikut:

a. Penelitian selanjutnya dengan topik yang sejenis, hendaknya menggunakan jangka waktu yang lebih panjang sehingga tingkat akurasi lebih tinggi serta memberikan gambaran lebih luas mengenai hubungan antara UMR dengan Inflasi.

b. Variabel-variabel yang digunakan dalam penelitian ini terbatas pada upah minimum regional dan inflasi saja. Kedepannya, untuk penelitian selanjutnya dapat ditambah dengan variabel lain yang relevan dengan topik penelitian.

c. Pihakyangberkepentingan dalam menetapkan upah minimum hendaknya memperhatikan inflasi sebagai salah satu faktor yang menjadi pertimbangan. Alasannya karena, ketika terjadi inflasi yang tidak disertai dengan kenaikan upah minimum, maka hal ini akan berakibat pada menurunnya upah riil yang diterima oleh pekerja.

\section{DAFTAR PUSTAKA}

Al-Qur'anulkarim. (2005). Al-Aliyy Al-Qur'an \& Terjemahnya. Bandung: Diponegoro

Afzalurrahman. (1997). Muhammad Sebagai Seorang Pedagang (Dewi Nurjulianti et.al., Penerjemah). Jakarta: Yayasan Swarna Bhumi.

Ananta, Aris. (1990). Ekonomi Sumber Daya Manusia. Jakarta: Lembaga Penerbitan Fakultas Ekonomi UI.

Ascarya. (2012). Alur Transmisi dan Efektifitas Kebijakan Moneter Ganda Di Indonesia. Buletin Ekonomi Moneter dan 
Perbankan. Vol. 14, No. 3. hlm. 283315.

Bambang Juanda \& Junaidi. (2012). Ekonometrika Deret Waktu: Teori \& aplikasi. Bogor: IPB Press.

Boediono. (2005). Ekonomi Makro. Edisi 4 cetakan ke dua puluh satu.Yogyakarta: BPFE-UGM.

Budianto Siallagan. (2015). Analisis Kausalitas Antara Upah Minimum dan Tingkat Inflasi di Kota Medan. Skripsi Universitas Sumatera Utara.

Cacnio, Chiristian Q. (2011). Do Higher Wages Cause Inflation?.BANGKO SENTRAL NG PILIPINASEconomic Newsletter. No. 11-01.

Djazuli. (2011). Kaidah-kaidah Fikih: kaidah-kaidah hukum Islam dalam menyelesaikan masalah-masalah yang praktis. Edisi 1 cetakan ke 4. Jakarta: Kencana.

Endang Setyowati dkk. (2004). Ekonomi Makro Pengantar. Yogyakarta: STIE Yogyakarta.

Gie, Kwik Kian. (1996).Praktek Bisnis dan Orientasi Ekonomi Indonesia. Jakarta: Gramedia.

Gujarati,DamodarN.(2004). Basic Econometrics. New York: McGraw-Hill.

Heri Setiawan. (2014). Upah Pekerja/Buruh Perspektif Hukum Positif Dan Hukum Islam. Skripsi UIN Sunan Kalijaga Yogyakarta.

Hess, Gregory D. (2000). Does Wage Inflation Cause Price Inflation?. Federal Reserve bank of cleveland, policy discussion paper no. 10 April.

HOXHA, Adriatik. (2010). causality between prices and wages: VECM analysis for EU-12. Theoritical and Applied Economics, vol. XVII. no. 5 (546), hlm. 27-28.
Jogiyanto. (2004). Metodologi Penelitian Bisnis: Salah Kaprah dan Pengalamanpengalaman. Yogyakarta: BPFE-UGM.

Jonsson \& Stefan. (2004). Do Higher Wages Cause Inflation?. Sveriges Riskbank Working Paper Series 159.

Kuncoro, Mudrajat. (2011).Metode Kuantitatif. Yogyakarta: UPP STIM YKPN.

Manan, M. Abdul. (1997). Teori dan Praktik Ekonomi Islam. Yogyakarta: Dana Bakti Wakaf.

Mohammadi, Ozra. (2014). Does Minimum wage cause inflation in iran?. International $J$. Soc. Sci. \& Education, vol. 4 June, hlm. 68-73.

Nopirin. (2000).Ekonomi Moneter.edisi pertama. Yogyakarta: BPFE-UGM.

Payaman. (1998).Pengantar Ekonomi Sumber Daya Manusia. Jakarta: Lembaga Penerbit Fakultas Ekonomi UI.

Peraturan Menteri Tenaga Kerja dan Transmigrasi Nomor 7 Tahun 2013 tentang Upah Minimum

Peraturan Menteri Tenaga Kerja Nomor 13 tahun 2012 Tentang Komponen Dan Pelaksanaan Komponen dan Pelaksanaan Tahapan Pencapaian Kebutuhan Hidup Layak

Pusat Pengembangan dan Penelitian Ekonomi Islam UII. (2008).Ekonomi Islam. Jakarta: Rajawali Press.

Rianto, Nur. (2010). Teori Makro Ekonomi Islam Konsep, Teori dan Analisis. Bandung: Alfabeta.

Safrida dkk. (2014). Dampak Peningkatan Upah Minimum Provinsi terhadap Inflasi dan Pasar Kerja di Provinsi Aceh.Agrisep. Vol. 15, No. 2. hlm. 45.

Samuelson, Paul A., \& William D. Nordhaus. (2001). Ilmu Makro Ekonomi. (Gretta, Theresa Tanoto, Basco Carvallo, Anna Elly, Penerjemah). Edisi 17. Jakarta: Erlangga. 
Sari H., Andi Reina. (2012). Model Proyeksi Inflasi Regional Jawa Tengah. Tesis Universitas Diponegoro Semarang.

Shochrul R. Ajija dkk. (2011). Cara Cerdas Menguasai Eviews. Jakarta: Salemba Empat.

Sholeh, Maimun. (2007). Permintaan dan Penawaran Tenaga Kerja serta Upah: Teori serta Beberapa Potretnya di Indonesia. Jurnal Ekonomi \& Pendidikan. Vol. 4, No. 1. hlm. 62-75.

Sukirno, Sadono. (1997).Pengantar Teori Makroekonomi. Jakarta: Raja grafindo persada.

Undang-undang Republik Indonesia No. 13 Tahun 2003 tentang Ketenagakerjaan
Widarjono, Agus. (2013).Ekonometrika Pengantar dan Aplikasinya. Yogyakarta: Ekonosia-FEUII.

Williamson, Stephen D. (2014). Macroeconomics. Edisi 5. USA: Pearson.

Winarno, Wing Wahyu. (2015). Analisis Ekonometrika dan Statistika dengan Eviews. Edisi 4 cetakan pertama. Yogyakarta: UPP STIM YKPN.

Zaenal, Veithzal Rivai. (2014). Islamic Human Capital Management: Manajemen Sumber Daya Insani. Jakarta: Rajawali Pers. 